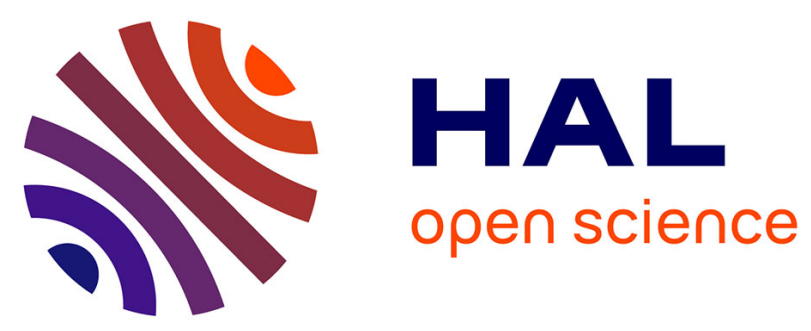

\title{
High-intensity exercise acutely decreases the membrane content of MCT1 and MCT4 and buffer capacity in human skeletal muscle
}

\author{
David J. Bishop, Johann Edge, Claire Thomas, Jacques Mercier
}

\section{- To cite this version:}

David J. Bishop, Johann Edge, Claire Thomas, Jacques Mercier. High-intensity exercise acutely decreases the membrane content of MCT1 and MCT4 and buffer capacity in human skeletal muscle. Journal of Applied Physiology, 2007, 102, pp.616-621. 10.1152/japplphysiol.00590.2006 . hal01587015

\section{HAL Id: hal-01587015 https://hal-insep.archives-ouvertes.fr/hal-01587015}

Submitted on 13 Sep 2017

HAL is a multi-disciplinary open access archive for the deposit and dissemination of scientific research documents, whether they are published or not. The documents may come from teaching and research institutions in France or abroad, or from public or private research centers.
L'archive ouverte pluridisciplinaire HAL, est destinée au dépôt et à la diffusion de documents scientifiques de niveau recherche, publiés ou non, émanant des établissements d'enseignement et de recherche français ou étrangers, des laboratoires publics ou privés. 


\title{
High-intensity exercise acutely decreases the membrane content of
}

\section{MCT1 and MCT4 and buffer capacity in human skeletal muscle}

\author{
David Bishop, ${ }^{1}$ Johann Edge, ${ }^{1}$ Claire Thomas, ${ }^{2,3}$ and Jacques Mercier ${ }^{2}$ \\ ${ }^{1}$ School of Human Movement and Exercise Science, The University of Western Australia, Crawley, Western \\ Australia, Australia; ${ }^{2}$ EA 701 Muscles et Pathologies Chroniques, Département de Physiologie des \\ Interactions, Faculté de Médecine, Institut de Biologie, Montpellier, France; and ${ }^{3}$ Laboratoire d'Etude de \\ la Physiologie de l'Exercice, Departement Sciences et Techniques des Activités Physiques et Sportives, \\ Unité de Formation et de Recherche des Sciences Fondamentales et Appliquées, Evry, France
}

The regulation of intracel- lular $\mathrm{pH}$ during intense muscle contractions occurs via a number of different transport systems [e.g., monocarboxylate transporters

(MCTs)] and via intracellular buffering $\left(13 \mathrm{~m}_{\text {in vitro }}\right)$. The aim of this study was to investigate the effects of an acute bout of high-intensity exercise on both MCT relative abundance and $13 \mathrm{~m}_{\text {in vitro }}$ in humans. Six active women volunteered for this study. Biopsies of the vastus lateralis were obtained at rest and immediately after $45 \mathrm{~s}$ of exercise

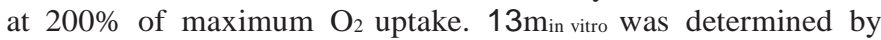
titration, and MCT relative abundance was determined in membrane preparations by Western blots. High-intensity exercise was associated with a significant decrease in both MCT1 (-24\%) and MCT4 ($26 \%)$ and a decrease in $13 m_{\text {in vitro }}(-11 \% ; 135 \pm 3$ to $120 \pm 2$ $\mu \mathrm{mol} \mathrm{H}^{+} \cdot \mathrm{g}$ dry muscle $\left.{ }^{-1} \cdot \mathrm{pH}^{-1} ; P<0.05\right)$. These changes were consistently observed in all subjects, and there was a significant correlation between changes in MCT1 and MCT4 relative abundance $\left(R^{2}=0.92 ; P<0.05\right)$. In conclusion, a single bout of high-intensity exercise decreased both MCT relative abundance in membrane preparations and $13 \mathrm{~m}_{\text {in vitro. Until the time course of these changes has been }}$ established, researchers should consider the possibility that observed training-induced changes in MCT and $13 \mathrm{~m}_{\text {in vitro }}$ may be influenced by the acute effects of the last exercise bout, if the biopsy is taken soon after the completion of the training program. The implications that these findings have for lactate $\left(\right.$ and $\mathrm{H}^{+}$) transport following acute, exhaustive exercise warrant further investigation.

buffer capacity; lactate transport; hydrogen ions

THE REMOVAL OF $\mathrm{H}^{+}$DURING INTENSE skeletal muscle contractions occurs via a number of different transport systems and via intracellular buffering $(23,24)$. Intracellular buffer capacity is typically estimated by titrating a muscle homogenate with a fixed acid $\left(13 \mathrm{~m}_{\text {in vitro }}\right)$ and measures the contribution of physicochemical buffering by proteins, dipeptides, and phosphates within the muscle (i.e., nonbicarbonate buffering). Lactate uptake and release is largely mediated by monocarboxylate transporters (MCTs) that are stereo-selective for L-(+)-lactate and $\mathrm{pH}$ dependent $(25,35)$. Sarcolemmal lactate transporters have also been suggested to have an important role in the regulation of intracellular $\mathrm{pH}$ (23).

Although 14 MCTs are known to exist (21), lactate $/ \mathrm{H}^{+}$ transport in skeletal muscle is currently attributed to two

Address for reprint requests and other correspondence: D. Bishop, School of Human Movement and Exercise Science, The Univ. of Western Australia, Crawley, WA 6009, Australia (e-mail: dbishop@cyllene.uwa.edu.au). isoforms (MCT1 and MCT4; Refs. 25, 33, 45). Chronic skeletal muscle activity exerts a strong influence on the expression of MCTs. Inactivity (denervation and hindlimb suspension) reduces MCT1 and MCT4 expression (45), while training increases MCT1 and MCT4 expression (4, 33). This altered density of membrane transporter proteins has been reported to be of functional importance for the translocation of $\mathrm{H}^{+}$and lactate from the muscle to the blood during high-intensity exercise (22). Training has also been reported to increase $13 \mathrm{~m}_{\text {in vitro }}(2,14-16,39)$.

In contrast to the many training studies, very few studies have investigated the effects of an acute bout of muscle activity on MCT abundance. However, increases in MCT have been observed 2-6 days after a 5- to 6-h training session in humans (19) and immediately following a 2-h treadmill session in rats (8). Changes in MCT following an acute bout of high-intensity muscle activity are more controversial. In the only study to date, it was reported that, in rats, immediately following 10 min of high-intensity electrical stimulation, there was a decrease in the plasma membrane MCT1 (-10\%) and MCT4 ($25 \%$ ) (44). However, in an additional experiment (conducted as part of the same study), the 10-min contraction period reduced MCT4 $(-20 \%)$, but not MCT1. To date, the results of this study have not been replicated in humans or in response to high-intensity exercise.

The aim of this study was to investigate the effects of an acute bout of high-intensity exercise on MCT relative abundance in humans. We hypothesized that a high-intensity exercise stimulus would decrease the relative abundance of both MCT1 and MCT4 in human skeletal muscle.

\section{METHODS}

Subjects. Six active women [age: $19 \pm 3 \mathrm{yr}$, mass: $63.1 \pm 3.2 \mathrm{~kg}$, peak $\mathrm{O}_{2}$ uptake $\left(\dot{\mathrm{V}}_{2}\right.$ peak $\left.): 46.7 \pm 3.2 \mathrm{ml} \cdot \mathrm{kg}^{-1} \cdot \mathrm{min}^{-1}\right]$ volunteered to participate in the study. Each subject was involved in an intermittent sport at club level(2-3 times/wk of hockey, netball, tennis, basketball, or football). All of the subjects completed a familiarization trial of a graded exercise test (GXT) and a 45-s constant-intensity exercise test ( $200 \% \dot{V}_{\text {O }}$ peak; CIT 45 ) before the main trial (where muscle biopsies were take pre- and immediately postexercise). Subjects were informed of the study requirements, benefits, and risks before giving written, informed consent. Approval for the study's procedures was granted by the University of Western Australia Research Ethics Committee. Subjects were required to consume no food or beverages (other than 
water) $2 \mathrm{~h}$ before testing and were asked not to consume alcohol or caffeine, or to perform vigorous exercise, in the $24 \mathrm{~h}$ before testing.

Graded exercise test. The graded exercise test (GXT) was performed on an air-braked track-cycle ergometer (Evolution Pty., Adelaide, Australia) and consisted of graded exercise steps (4-min stages), using an intermittent protocol (1-min break between stages). The test commenced at $50 \mathrm{~W}$, and, thereafter, intensity was increased by $30 \mathrm{~W}$ every 4 min until volitional exhaustion.

Gas analysis during the GXT. During the GXT, expired air was continuously analyzed for $\mathrm{O}_{2}$ and $\mathrm{CO}_{2}$ concentrations using Ametek gas analyzers (SOV S-3A11 and COV CD-3A, Applied Electrochemistry, Pittsburgh, PA). Ventilation was recorded every $15 \mathrm{~s}$ using a turbine ventilometer (225A, Morgan, Kent, UK). The gas analyzers were calibrated immediately before and verified after each test using three certified gravimetric gas mixtures (BOC Gases, Chatswood, NSW, Australia); the ventilometer was calibrated preexercise and verified postexercise using a 1-liter syringe, in accordance with the manufacturer's instructions. The ventilometer and gas analyzers were connected to an IBM PC, which measured and displayed variables every $15 \mathrm{~s}$. The sum of the two highest consecutive 15 -s values was recorded as the subject's $\dot{\mathrm{V}}_{2}$ peak.

CIT 45 . The high-intensity cycle test consisted of $45 \mathrm{~s}$ of continuous cycling at a set power output $(408 \pm 34 \mathrm{~W})$ on an air-braked, frontaccess cycle ergometer (model Ex-10, Repco). Toe clips and heel straps were used to secure the feet to the pedals, and the test was performed in the seated position. Strong verbal encouragement was provided to each subject during the test. The power output for the $\mathrm{CIT}_{45}$ was set as $200 \%$ of the mean power output at $\dot{\mathrm{V}}_{2}$ peak intensity.

Muscle sampling and analysis. On the day of the $\mathrm{CIT}_{45}$ cycle test, incisions were made under local anesthesia $(5 \mathrm{ml}, 1 \%$ xylocaine) into the vastus lateralis of each subject (midway between the anterior, superior iliac spine, and the patella). The first muscle sample was taken (before warm up) during supine rest. The second muscle sample was taken immediately (within $10 \mathrm{~s}$ ) following the cessation of the $\mathrm{CIT}_{45}$, while the subject remained on the cycle ergometer. The samples were then removed from the biopsy needle and immediately stored at $-80^{\circ} \mathrm{C}$ until subsequent analysis.

ATP,$P C r$, and La determination. Freeze-dried rest and postexercise muscle samples $(2-3 \mathrm{mg})$ were dissected free from visible blood, fat, and connective tissue and then enzymatically assayed for ATP, phosphocreatine (PCr), and lactate ( $\left.\mathrm{La}^{-}\right)$content. ATP, PCr, and $\mathrm{La}^{-}$were extracted from muscle samples by the addition of $6 \%$ perchloric acid, before being centrifuged $(10,000 \mathrm{~g}$ X $10 \mathrm{~min})$. The supernatant was removed and neutralized by the addition of $2.4 \mathrm{~mol} / \mathrm{l}$ $\mathrm{KOH}$ and $3 \mathrm{~mol} / \mathrm{l} \mathrm{KCl}$. Samples were centrifuged again, and the supernatant was stored at ${ }^{-} 80^{\circ} \mathrm{C}$. ATP, $\mathrm{PCr}$, and $\mathrm{La}^{-}$were measured as previously described (1).

Nonbicarbonate muscle buffering capacity; titration method $\left(13 m_{\text {in vitro }}\right)$ and $H^{+}$. Muscle samples were weighed pre- and postfreeze drying to determine water content. Freeze-dried muscle samples $(1.8-2.5 \mathrm{mg})$ were then homogenized on ice for $2 \mathrm{~min}$ in a solution containing sodium fluoride $(10 \mathrm{mM})$ at a dilution of $30 \mathrm{mg}$ dry muscle $(\mathrm{dm}) / \mathrm{ml}$ of homogenizing solution (29). The $\mathrm{pH}$ measurements were made at $37^{\circ} \mathrm{C}$ with a microelectrode (MI-415, Microelectrodes, Bedford, NH) connected to a $\mathrm{pH}$ meter (SA 520, Orion Research, Cambridge, MA). After initial pH measurement, muscle homogenates for both pre- and postexercise samples were adjusted to a $\mathrm{pH}$ of 7.2 with a sodium hydroxide $(0.02 \mathrm{M})$ solution and then titrated to a $\mathrm{pH}$ of 26.2 by the serial addition of $2 \mu$ of hydrochloric acid $(10 \mathrm{mM})$. From the fitted titration trend line, the number of moles of $\mathrm{H}^{+}$(per gram $\mathrm{dm}$ ) required to change the $\mathrm{pH}$ from 7.1 to 6.5 was interpolated. This value was then normalized to the whole $\mathrm{pH}$ unit for final display as micromoles $\mathrm{H}^{+}$per gram dm per unit $\mathrm{pH}\left(\mu \mathrm{mol} \mathrm{H} \mathrm{H}^{+} \cdot \mathrm{g}\right.$ muscle $\mathrm{dm}^{-1} \cdot \mathrm{pH}^{-1}$ ) and determined as the subject's $13 \mathrm{~m}_{\text {in vitro. }}$.

Sample preparation for Western blotting. Proteins were isolated from muscles for Western blotting by a standard method previously described by McCullagh et al. (30) with slight modifications that our laboratory has previously described $(10,43)$. Briefly, total muscle membranes were obtained from $\$ 40 \mathrm{mg}$ of frozen skeletal muscle and gently homogenized, using a glass mortar and pestle, in $1 \mathrm{ml}$ of ice-cold buffer (in mM: $30 \mathrm{~N}$-2-hydroxyethylpiperazine- $N$ '-2-ethanesulfonic acid, $\mathrm{pH} 7.4,210$ sucrose, 2 ethylene glycol-bis(13-aminoethyl ether)- $N, N, N^{\prime}, N^{\prime}$-tetraacetic acid, $40 \mathrm{NaCl}$, and 5 EDTA). The homogenate was then centrifuged at $800 \mathrm{~g}$ for $10 \mathrm{~min}$ at $4^{\circ} \mathrm{C}$ to remove red blood cells. The supernatant was subsequently mixed with $750 \mu \mathrm{l}$ of $1.167 \mathrm{M} \mathrm{KCl}$ plus $58.3 \mathrm{mM}$ pyrophosphate and centrifuged at $40,000 \mathrm{~g}$ for $105 \mathrm{~min}$ at $5^{\circ} \mathrm{C}$ to remove myosin and contractile proteins. The pellet was solubilized in $16.5 \mu \mathrm{l}$ of $16 \%$ SDS and $50 \mu \mathrm{l}$ of $10 \mathrm{mM}$ Tris and $1 \mathrm{mM}$ EDTA, pH 7.4. Total membranes were recovered by centrifugation at $20^{\circ} \mathrm{C}$ for $20 \mathrm{~min}$ at $1,100 \mathrm{~g}$. The supernatant was stored in aliquots at $-70^{\circ} \mathrm{C}$ for subsequent determinations of protein and Western blotting. Muscle protein concentrations were determined in duplicate by bicinchoninic acid assay (Pierce, Interchim, Montluçon, France) with the use of BSA as a standard. There was no significant difference between pre- and postexercise muscle samples for the amount of muscle homogenized (33.7 \pm 7.8 vs. $39.6 \pm 10.7 \mathrm{mg} ; P>0.05)$ or the normalized protein yield $(6.7 \pm 1.4$ vs. $6.5 \pm 1.9 \mathrm{mg} / \mathrm{g}$ tissue; $P>0.05)$.

Western blotting of the MCT1 and MCT4. MCT abundance was determined using previously described methods (43). Polyclonal antibodies yielded a single band on a Western blot that corresponded to $43 \mathrm{kDa}$, consistent with the molecular mass reported earlier (30). Antibody specificities were confirmed in preliminary experiments in which the peptides blocked the detection of MCT1 and MCT4. Membranes were washed as previously described, and MCT1 or MCT4 expression was detected by enhanced chemiluminescence (Biomax MR films, Kodak, Reuil-Malmaison, France). Films were developed and processed using a Hyperprocessor, RNP 1700 (Amersham, Les Ulis, France). MCT1 and MCT4 protein band densities were determined by scanning the blots on a scanner (AGFA Duo Scan T1200, New York, NY) and Scion Image software (Scion, Frederick, $\mathrm{MD})$. Results were expressed in arbitrary optical density units, as used by others (43).

Statistical analysis. All values are reported as means \pm SD. One-way ANOVA with repeated measures for time were used to test for main effects for measurements. Least squares linear regression analysis was used to calculate correlation coefficients between changes in MCT1, MCT4, and $13 \mathrm{~m}_{\text {in vitro, using Pearson's product }}$ moment $(r)$. Significance was accepted at $P<0.05$.

\section{RESULTS}

Muscle metabolites and $\mathrm{pH}$. Muscle metabolite and $\mathrm{pH}$ data measured before and after the 45-s cycle test are summarized in Table 1. Postexercise, there was a significant decrease in ATP, $\mathrm{PCr}$, and $\mathrm{pH}$ and a significant increase in $\mathrm{La}^{-}$. There were no significant changes in muscle water content from preto postexercise $(77.0 \pm 0.4$ to $76.9 \pm 0.3 \% ; P>0.05)$.

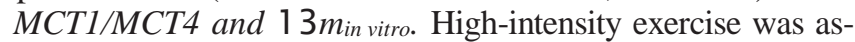
sociated with a signifi decrease in both MCT1 (24\%, Fig. 1) and MCT4 relative abundance (26\%, Fig. 2). Individual

Table 1. Skeletal muscle metabolites and $\mathrm{pH}$ at rest and immediately after the 45-s cycle test

\begin{tabular}{lcl}
\hline \multicolumn{1}{c}{ Variable } & Preexercise & Postexercise \\
\hline $\mathrm{ATP}, \mathrm{mmol} / \mathrm{kg} \mathrm{dm}$ & $20.3 \pm 2.0$ & $14.7 \pm 2.2^{*}$ \\
$\mathrm{PCr}, \mathrm{mmol} / \mathrm{kg} \mathrm{dm}$ & $82.6 \pm 12.3$ & $49.0 \pm 14.2^{*}$ \\
$\mathrm{La}, \mathrm{mmol} / \mathrm{kg} \mathrm{dm}$ & $6.4 \pm 2.4$ & $70.0 \pm 21.2^{*}$ \\
$\mathrm{pH}$ & $7.11 \pm 0.07$ & $6.84 \pm 0.14^{*}$
\end{tabular}

Values are means \pm SD. PCr, phosphocreatine; $\mathrm{La}^{-}$, lactate; dm, dry muscle. * Significantly different from preexercise $(P<0.05)$. 


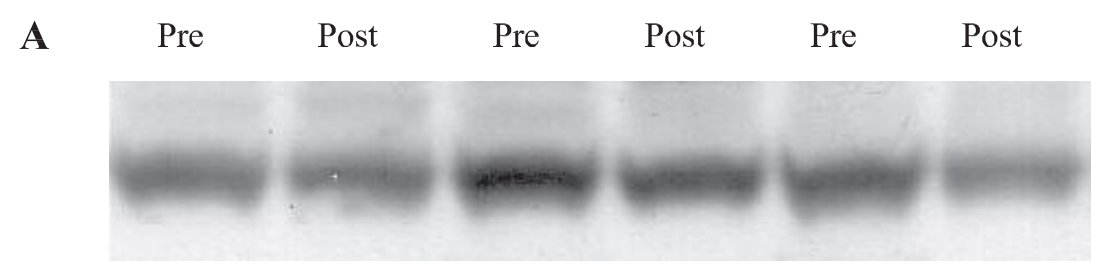

Fig. 1. A: representative monocarboxylate transporter (MCT) 1 blots in skeletal muscle biopsies taken from women before (Pre) and immediately after (Post) $45 \mathrm{~s}$ of highintensity exercise. $B$ : means $\pm \mathrm{SD}$ and individual changes in MCT1 relative abundance pre- and postexercise. S1-S6, subjects $1-6$. *Significant difference between pre- and postexercise $(P<0.05)$

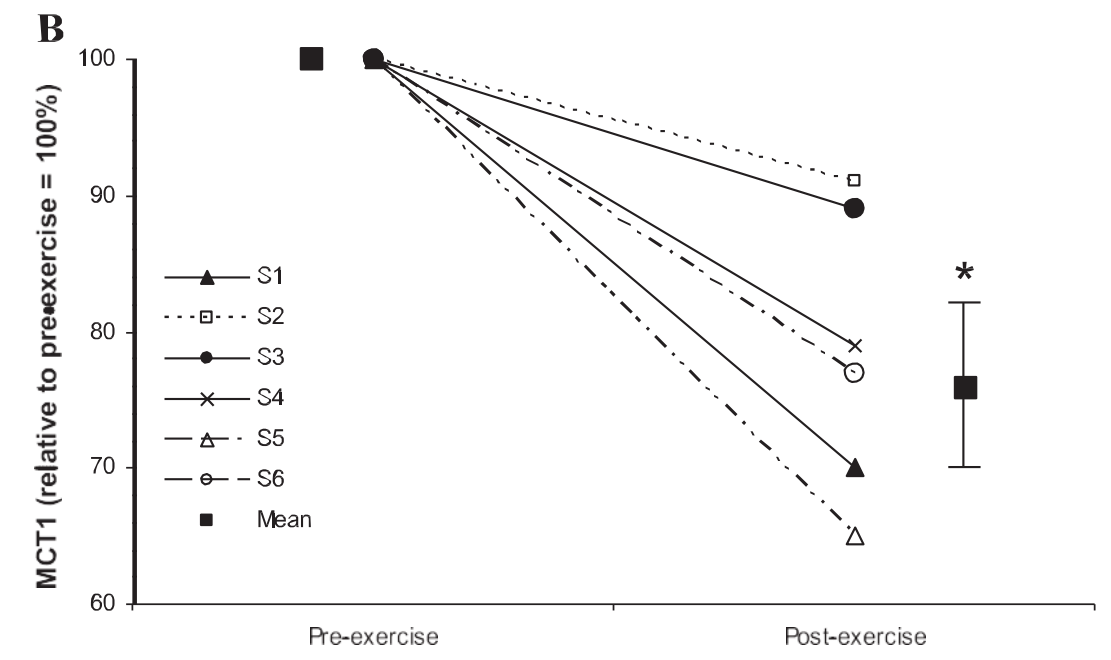

changes in both MCT1 and MCT4 are also plotted in Figs. 1 and 2, respectively. There was a significant correlation between changes in MCT1 and MCT4 relative abundance $\left(R^{2}=0.92\right.$; $P<0.05$ ).

Individual changes in $13 \mathrm{~m}_{\text {in vitro (along with mean values) are }}$ shown in Fig. 3. High-intensity exercise was associated with a significant decrease in $13 \mathrm{~m}_{\text {in vitro }}(135.4 \pm 10.8$ to $119.2 \pm 5.1$ $\left.\mu \mathrm{mol} \mathrm{H}+\mathrm{g} \mathrm{dm}^{-1} \cdot \mathrm{pH}^{-1} ; P<0.05\right)$. There were no significant correlations between changes in MCT1 and MCT4 relative abundance and changes in $13 \mathrm{~m}_{\text {in vitro }}(P>0.05)$.

\section{DISCUSSION}

This is the first study to report changes in MCTs and the nonbicarbonate, physicochemical buffer capacity following an acute bout of high-intensity exercise $\left(45 \mathrm{~s}\right.$ at $\left.200 \% \dot{\mathrm{V}}_{\mathrm{O}_{2} \text { peak }}\right)$ in humans. The observed large changes in muscle metabolites support the intense nature of the chosen protocol. The main results are that high-intensity exercise was associated with a significant decrease in both MCT1 (-24\%) and MCT4 ($26 \%)$ and a decrease in $13 m_{\text {in vitro }}(-11 \%)$.

Despite limited research, it appears that prolonged exercise $(>2 \mathrm{~h}$ ) can acutely increase MCT relative abundance in rats (8) and in humans (19). In contrast, in the only published study to date, $10 \mathrm{~min}$ of high-intensity electrical stimulation in rats was reported to decrease sarcolemmal MCT1 $(-10 \%, P<0.05)$ in one experiment but not another (percentage not reported, $P>$ $0.05)$ (44). There was also a consistent reduction in MCT4 $(20-25 \%, P<0.05)$ in both experiments, which was of a similar magnitude to that observed in the present study. Thus our findings are consistent with the only previous rat study and support the hypothesis that brief, high-intensity exercise can acutely decrease relative MCT abundance in humans.
While 45 s represents a very brief stimulus, a recent study, using quantitative proteomics, has reported an acute decrease in the level of another protein (creatine kinase) in response to only $3 \mathrm{~min}$ of intense swimming exercise in rats (20). Furthermore, increases in enzyme activities of $200-2,500 \%$ have been reported in humans after 10 min of moderate-intensity exercise (27). In addition, the exercise-induced activation of enzymes reported by Krook et al. (27) was limited to working muscle, indicating that local rather than systemic factors activate these signaling cascades. Therefore, the combined results of these studies, along with the previous findings in rats (44), suggest that muscle proteins are able to respond to local changes in the muscle, during high-intensity exercise, within the time frame observed in our study.

Dismissing the $10 \%$ decrease in MCT1 in one part of their experiment, Tonouchi et al. (44) proposed that no change in MCT1 and an acute decrease in MCT4 could be attributed to their earlier observation that MCT4, but not MCT1, exists in an intracellular pool (5). Thus they hypothesized that MCT4, but not MCT1, may translocate to an intracellular pool. To date, no other research group has verified the existence of intracellular pools of MCT4 (or MCT1). However, other similar sized proteins (e.g., GLUT-4) do exist in intracellular pools and have been reported to reversibly translocate following exercise (26). While the existence of intracellular pools could not be verifi from our protein preparation, it is possible that an intracellular pool of MCT1 is yet to be discovered or that changes in MCT can occur without a preexisting intracellular pool. A decrease in plasma membrane MCT1 has previously been reported to occur without the detection of a preexisting intracellular pool (44).

Loss of lactate transporters could also result from freeradical-induced lipid peroxidation (11). Exhaustive exercise 
A

Pre

Post

Pre

Post

Pre

Post

B

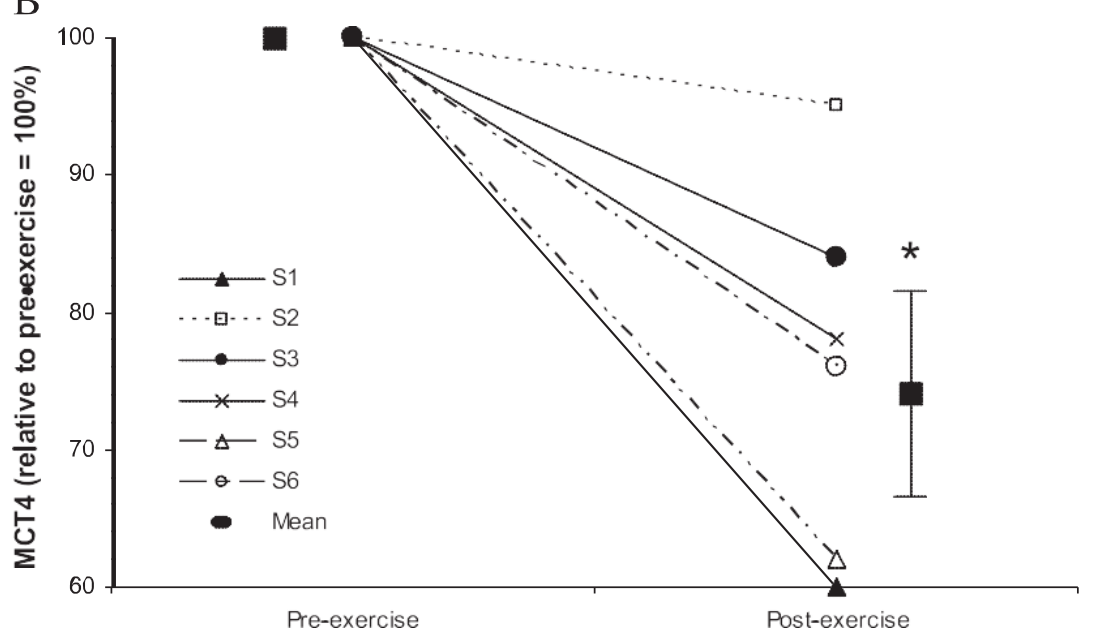

Fig. 2. A: representative MCT4 blots in skeletal muscle biopsies taken from women before and immediately after $45 \mathrm{~s}$ of high-intensity exercise. $B$ : means $\pm \mathrm{SD}$ and individual changes in MCT4 relative abundance pre- and postexercise. *Significant difference between pre- and postexercise $(P<0.05)$.

increases free-radical concentration (9), and it has been suggested that peroxidation of polyunsaturated fatty acids may lead to fluidity and permeability alterations in the membrane $(9,38)$. The decrease in the relative abundance of MCT could, therefore, result from its release out of muscle due to exerciseinduced muscle damage.

The short time frame in which these changes occurred raises the possibility that our results represent an artifactual effect due to a contraction-induced vascular fluid shift into muscle (36, 40) or an alteration in the degree of protein extraction (34).
However, an acute change in muscle water content appears unlikely to explain our results, as the same amount of protein was loaded on all gels and there was no significant change in muscle water content. While previous human studies have reported significant exercise-induced increases in muscle water content (277-79\%), these studies have involved exhaustive exercise of much longer duration than the present study (\$6-15 min; Refs. 28, 36, 40).

Alternatively, changed levels of a given protein could result from an alteration in the degree of protein extraction, since the

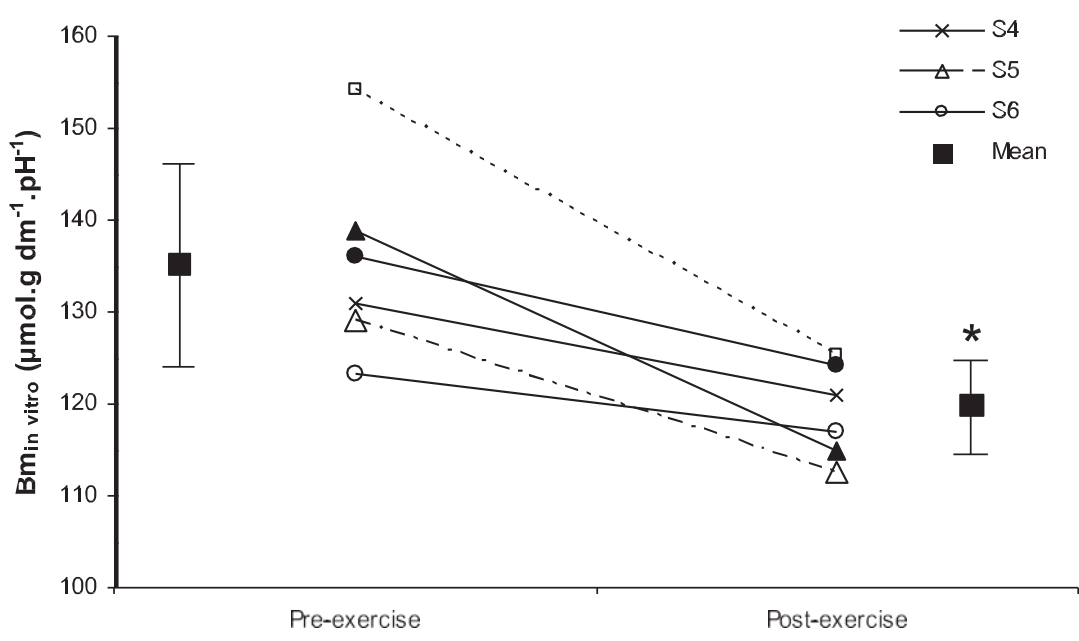

Fig. 3. Individual changes in titrated muscle buffer capacity

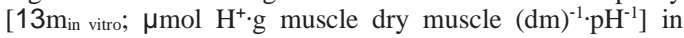
skeletal muscle biopsies taken from women before and immediately after $45 \mathrm{~s}$ of high-intensity exercise. Also plotted are the mean values. *Postexercise mean significantly different from preexercise mean $(P<0.05)$. 
degree of extraction of some muscle proteins is sensitive to muscle physiological state and level of activity (34). While the protein isolation technique that we used (30) is a well-established technique, which has been used in many published studies, it does involve fractionation steps with several steps of centrifugation and isolation of supernatant and unquestionably results in the incomplete recovery of protein. More importantly, it is not known if prior high-intensity exercise affects the recovery of MCT proteins using this technique. As the only other study to report an acute decrease in MCT also used this technique (44), we cannot exclude the possibility that these results reflect a reduced recovery of MCT protein postexercise. However, the absence of a significant difference in the concentration of protein isolated from pre- and postexercise muscle samples strongly argues against this possibility. Furthermore, if there were a decrease in MCT protein extraction postexercise, it would have to have been matched by a similar increase in the extraction of other unknown proteins, an unlikely scenario in our view.

The physiological significance of these findings is unclear, as the relationship between MCT abundance and lactate transport is complex. It has previously been reported that the rate of lactate flux into and out of the muscle is correlated with the content of MCT1 and MCT4 in the muscle $(5,6,30,31)$. Thus the decrease in MCT1 and MCT4 in the present study may be expected to decrease rates of lactate $\left(\right.$ and $\mathrm{H}^{+}$) removal from the cell. Furthermore, a decrease in lactate transport capacity has been reported following exhaustive exercise $(11,18)$. However, concomitant changes in lactate transport cannot be assumed in the present study, as changes in MCT1 and MCT4 content have not always been strongly associated with changes in muscle lactate concentration (19) or lactate transport $(17,44)$.

While previous research has investigated changes in

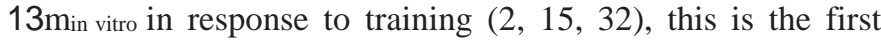
study to report a decrease in $13 m_{\text {in vitro }}(-11 \%)$ following an acute bout of exercise in humans. The mechanisms underlying the acute decrease in $13 \mathrm{~m}_{\text {in vitro }}$ cannot be determined from the results of this study, but are likely to be due to changes in the intracellular buffers that are measured using the in vitro titration technique (i.e., phosphates, proteins, and dipeptides). It has previously been reported that acute, intense exercise results in a small (?10\%), but significant, loss of carnosine from the muscle (13). Furthermore, a significant increase $(+20 \%)$ in plasma carnosine was observed following severe exercise in horses (12), indicating a loss of carnosine from the muscle. Due to its capacity to buffer $\mathrm{H}^{+}$within the typical physiological range experienced during high-intensity exercise $\left(\mathrm{p} K_{\mathrm{a}}=\right.$ 6.83 ), carnosine is an important intracellular buffer, and any loss from the muscle should cause a decrease in $13 \mathrm{~m}_{\text {in vitro }}$. Another potential mechanism underlying the decrease in

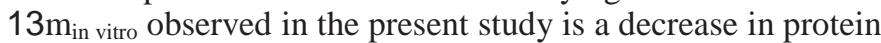
buffering, as metabolically induced acidosis has been reported to increase protein breakdown (7). It appears unlikely that the decrease in $13 m_{\text {in vitro }}$ can be attributed to an acute change in muscle phosphate concentration following high-intensity exercise. It has previously been reported that there is no significant decrease in the total adenine nucleotide pool (ATP + ADP + AMP) plus IMP following a 30-s maximal sprint (42) and no signifi change in total muscle phosphate following exercise to exhaustion at $75 \%$ of maximum $\mathrm{O}_{2}$ uptake (44-108 min) (37).
In conclusion, a single bout of high-intensity exercise decreased the membrane content of both MCT1 and MCT4 and

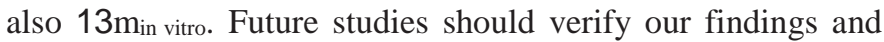
also examine the time course of the acute changes that we have reported. Until the time course of these changes has been established, researchers should consider the possibility that observed training-induced changes in MCT and 13min vitro may be influenced by the acute effects of the last exercise bout, if the biopsy is taken soon after the completion of the training program. Further research is also required to investigate the implications that these findings have for lactate (and $\mathrm{H}^{+}$) transport following acute, exhaustive exercise.

\section{REFERENCES}

1. Arthur P, Hochachka PW. Automated analysis of cellular metabolites at nanomolar to micromolar concentrations using bioluminescent methods. Anal Biochem 227: 281-284, 1995.

2. Bell GJ, Wenger A. The effect of one-legged sprint training on intramuscular $\mathrm{pH}$ and nonbicarbonate buffering capacity. Eur J Appl Physiol 58: 158-164, 1988.

3. Bonen A, Luiken JJFP, Arumugam Y, Glatz JFC, Tandon NN. Acute regulation of fatty acid uptake involves the cellular redistribution of fatty acid translocase. J Biol Chem 275: 14501-14508, 2000.

4. Bonen A, McCullagh KJA, Putman CT, Hultman E, Jones NL, Heigenhauser GJF. Short-term training increases human muscle MCT1 and femoral venous lactate in relation to muscle lactate. Am J Physiol Endocrinol Metab 274: E102-E107, 1998.

5. Bonen A, Miskovic D, Tonouchi M, Lemieux K, Wilson MC, Marette A, Halestrap AP. Abundance and subcellular distribution of MCT1 and MCT4 in heart and fast-twitch skeletal muscles. Am J Physiol Endocrinol Metab 278: E1067-E1077, 2000.

6. Bonen A, Tonouchi M, Miskovic D, Heddle C, Heikkila JJ, Halestrap AP. Isoform-specific regulation of the lactate transporters MCT1 and MCT4 by contractile activity. Am J Physiol Endocrinol Metab 279: E1131-E1138, 2000.

7. Caso G, Garlick BA, Casella GA, Sasvary D, Garlick PJ. Acute metabolic acidosis inhibits muscle protein synthesis in rats. Am J Physiol Endocrinol Metab 287: E90-E96, 2004.

8. Coles L, Litt J, Hatta H, Bonen A. Exercise rapidly increases expression of the monocarboxylate transporters MCT1 and MCT4 in rat muscle. J Physiol 561: 253-261, 2004.

9. Davies KJA, Quintanilha A, Brooks G, Packer L. Free radicals and tissue damage produced by exercise. Biochem Biophys Res Commun 107: $1198-1205,1982$.

10. Dubouchaud H, Butterfield GE, Wolfel EE, Bergman BC, Brooks GA. Endurance training, expression, and physiology of LDH, MCT1, and MCT4 in human skeletal muscle. Am J Physiol Endocrinol Metab 278. E571-E579, 2000.

11. Dubouchaud H, Eydoux N, Granier P, Prefaut C, Mercier J. Lactate transport activity in rat skeletal muscle sarcolemmal vesicles after acute exhaustive exercise. J Appl Physiol 87: 955-961, 1999.

12. Dunnett M, Harris RC, Dunnett CE, Harris PA. Plasma carnosine concentration: diurnal variation and effects of age, exercise and muscle damage. Equine Vet J Suppl 34: 283-287, 2002.

13. Dupin A, Stvolinski S. Changes in carnosine levels in muscles working in different regimens of stimulation. Biokhimiia 51: 160-164, 1986.

14. Edge J, Bishop D, Goodman C. Effects of chronic $\mathrm{NaHCO}_{3}$ ingestion during interval training on changes to muscle buffer capacity, metabolism, and short-term endurance performance. J Appl Physiol 101: 918-925, 2006.

15. Edge J, Bishop D, Goodman C. The effects of training intensity on muscle buffer capacity in females. Eur J Appl Physiol 96: 97-105, 2006.

16. Edge J, Bishop D, Hill-Haas S, Goodman C. Comparison of muscle buffer capacity and repeated-sprint ability of untrained, endurance-trained and team-sport athletes. Eur J Appl Physiol 96: 225-234, 2006.

17. Eydoux N, Dubouchaud H, Py G, Granier P, Prefault C, Mercier J. Lactate transport in rat sarcolemmal vesicles after a single bout of submaximal exercise. Int J Sports Med 21: 393-399, 2000.

18. Eydoux N, Py G, Lambert K, Dubouchaud H, Prefaut C, Mercier J. Training does not protect against exhaustive exercise-induced lactate 
transport capacity alterations. Am J Physiol Endocrinol Metab 278: E1045-E1052, 2000.

19. Green H, Halestrap A, Mockett C, O'Toole D, Grant S, Ouyang J. Increases in muscle MCT are associated with reductions in muscle lactate after a single exercise session in humans. Am J Physiol Endocrinol Metab 282: E154-E160, 2002.

20. Guelfi K, Casey T, Giles J, Fournier P, Arthur P. A proteomic analysis of the acute effects of high-intensity exercise on skeletal muscle proteins in fasted rats. Clin Exp Pharmacol Physiol 33: 952-957, 2006.

21. Halestrap A, Meredith D. The SLC16 gene family-from monocarboxylate transporters (MCTs) to aromatic amino acid transporters and beyond Pflügers Arch 447: 619-628, 2004.

22. Juel C. Current aspects of lactate exchange: lactate $/ \mathrm{H}^{+}$transport in human skeletal muscle. Eur J Appl Physiol 86: 12-16, 2001.

23. Juel C. Lactate-proton cotransport in skeletal muscle. Physiol Rev 77 : 321-358, 1997.

24. Juel C. Muscle pH regulation: role of training. Acta Physiol Scand 162: 359-366, 1998.

25. Juel C, Halestrap A. Lactate transport in skeletal muscle-role and regulation of the monocarboxylate transporter. J Physiol 517: 633-642, 1999.

26. Kandror KV, Pilch PF. Compartmentalization of protein traffic in insulin-sensitive cells. Am J Physiol Endocrinol Metab 271: E1-E14, 1996.

27. Krook A, Widegren U, Jiang XJ, Henriksson J, Wallberg-Henriksson H, Alessi D, Zierath JR. Effects of exercise on mitogen- and stressactivated kinase signal transduction in human skeletal muscle. Am J Physiol Regul Integr Comp Physiol 279: R1716-R1721, 2000.

28. Krustrup P, Ferguson RA, Kjaer M, Bangsbo J. ATP and heat production in human skeletal muscle during dynamic exercise: higher efficiency of anaerobic than aerobic ATP resynthesis. J Physiol 549: 255-269, 2003.

29. Mannion AF, Jakeman PM, Willan PLT. Determination of human skeletal muscle buffer value by homogenate technique: methods of measurement. J Appl Physiol 75: 1412-1418, 1993.

30. McCullagh KJ, Poole RC, Halestrap AP, O'Brien M, Bonen A. Role of the lactate transporter (MCT1) in skeletal muscles. Am J Physiol Endocrinol Metab 271: E143-E150, 1996.

31. McCullagh KJ, Poole RC, Halestrap AP, Tipton KF, O'Brien M, Bonen A. Chronic electrical stimulation increases MCT1 and lactate uptake in red and white skeletal muscle. Am J Physiol Endocrinol Metab 273: E239-E246, 1997.

32. Nevill ME, Boobis LH, Brooks S, Williams C. Effect of training on muscle metabolism during treadmill sprinting. J Appl Physiol 67: 23762382, 1989.
33. Pilegaard H, Domino K, Noland T, Juel C, Hellsten Y, Halestrap AP, Bangsbo J. Effect of high-intensity exercise training on lactate $/ \mathrm{H}^{+}$transport capacity in human skeletal muscle. Am J Physiol Endocrinol Metab 276: E255-E261, 1999.

34. Rathgeber B, Pato M, Boles J, Shand P. Rapid post-mortem glycolysis and delay of chilling of turkey carcasses cause alterations to protein extractability and degradation of breast muscle proteins. J Agric Food Chem 47: 2529-2536, 1999.

35. Roth DA. The sarcolemmal lactate transporter: transmembrane determinants of lactate flux. Med Sci Sports Exerc 23: 925-934, 1991.

36. Sahlin K, Alverstrand A, Brandt R, Hultman E. Intracellular pH and bicarbonate concentration in human muscle during recovery from exercise. J Appl Physiol 45: 474-480, 1978.

37. Sahlin K, Soderlund K, Tonkonogi M, Hirakoba K. Phosphocreatine content in single fibers of human muscle after sustained submaximal exercise. Am J Physiol Cell Physiol 273: C172-C178, 1997.

38. Sen CK. Oxidants and antioxidants in exercise. J Appl Physiol 79: 675-686, 1995.

39. Sharp RL, Costill DL, Fink WJ, King DS. Effects of eight weeks of bicycle ergometer training on human muscle buffer capacity. Int J Sports Med 7: 13-17, 1986.

40. Sjogaard G, Adams RP, Saltin B. Water and ion shifts in skeletal muscle of humans with intense dynamic knee extension. Am J Physiol Regul Integr Comp Physiol 248: R190-R196, 1985.

41. Srere P. Citrate synthase. Methods Enzymol 13: 3-5, 1969.

42. Stathis CG, Febbraio MA, Carey MF, Snow RJ. Influence of sprint training on human skeletal muscle purine nucleotide metabolism. $J$ Appl Physiol 76: 1802-1809, 1994.

43. Thomas C, Perrey S, Lambert K, Hugon G, Mornet D, Mercier J. Monocarboxylate transporters, blood lactate removal after supramaximal exercise, and fatigue indexes in humans. J Appl Physiol 98: 804-809, 2005.

44. Tonouchi M, Hatta H, Bonen A. Muscle contraction increases lactate transport while reducing sarcolemmal MCT4, but not MCT1. Am J Physiol Endocrinol Metab 282: E1062-E1069, 2002.

45. Wilson MC, Jackson VN, Heddle C, Price NT, Pilegaard H, Juel C, Bonen A, Montgomery I, Hutter OF, Halestrap AP. Lactic acid efflux from white skeletal muscle is catalyzed by the monocarboxylate transporter isoform MCT3. J Biol Chem 273: 15920-15926, 1998.

46. Yoshida Y, Hatta H, Kato M, Enoki T, Kato H, Bonen A. Relationship between skeletal muscle MCT1 and accumulated exercise during voluntary wheel running. J Appl Physiol 97: 527-534, 2004. 